Research, part of a Special Feature on $\underline{\text { Scale and Governance }}$

\title{
Economic Governance to Expand Commercial Wetlands: Within- and Cross-Scale Challenges
}

\author{
$\underline{\text { Arianne T. de Blaeij }}^{1}$, Nico Polman $^{1}$, and Stijn Reinhard ${ }^{1}$
}

\begin{abstract}
Commercial wetlands are defined as wetlands directed by an entrepreneur with the intention of making a profit. The combination of ecosystem services that commercial wetlands can provide seems to be an attractive societal perspective. Nevertheless, these wetlands are not developed on a large scale in the Netherlands. This paper discusses different types of economic governance that could facilitate the development of new commercial wetlands and addresses challenges that have to be overcome. We conclude that developing governance solutions that address ecosystem services with different scales is crucial for the introduction of commercial wetlands. Also, distinct and autonomous property rights of entrepreneurs need to be addressed.
\end{abstract}

Key Words: commercial ecosystem; economic governance; economic value; ecosystem management; ecosystem services; multifunctional land use; PES systems; scaling; social-ecological systems

\section{INTRODUCTION}

Europe, and in particular the Netherlands, has to cope with numerous problems in its water management because of climate change, soil subsidence, and surface water pollution (de Jonge 2009). Droughts and floods are examples of these problems. The Dutch government expects that waterlogging problems in rural areas will increase (Ministry of Transport, Public Works and Water Management 2007). Rural areas are able to offer local and regional solutions in which water and land management can be adapted to reduce the aforementioned problems and also decrease nitrate and phosphate emissions to water bodies. In this paper, we examine the introduction of commercial wetlands as a form of multifunctional land use. These are defined as wetlands directed on a voluntary basis by an entrepreneur with the intention of making a profit and an extra opportunity to earn an income. The benefits of commercial wetlands are defined as ecosystem services (Millennium Ecosystem Assessment 2005).

Commercial wetlands produce various ecosystem services that are currently not traded on a market, implying that the entrepreneur will not be compensated for his efforts. To encourage entrepreneurs to develop commercial wetlands, adequate incentives for the provision of wetland services are needed, including a private income that can be earned by exploiting a wetland. Kroeger and Casey (2007) highlight that government payments may be the most effective incentive for ecosystem services that the private sector can provide. In practice, intermediaries are frequently setting the price for public services, with users often unaware of the fact that they pay (Vatn 2010). Institutional aspects of providing adequate incentives are important for commercial wetlands. We will analyze how economic governance can align private investment decisions with a socially optimal allocation.

The objective of this paper is to identify the challenges involved when attempting to establish economic governance to create financial incentives reflecting the value of commercial ecosystem services. Economic governance should enable the development and implementation of Payments for Ecosystem Services (PES) systems (Vatn 2010). These systems involve the voluntary transaction 
between an ecosystem service provider and an ecosystem service buyer. Because wetlands produce an array of different ecosystem services, economic, ecological, and institutional perspectives have to be combined to determine the adequate economic governance to facilitate the introduction of commercial wetlands.

Recently, there has been a wide interest in PES systems. However, little attention has been devoted to constructing the remuneration of this service on the economic value of the provided ecosystem (e.g., Wünscher et al. 2008). As the value of ecosystem services depends on the demand, the economic value is not equal among different landowners, neither does the value depend on the income position of the landowner. A PES system paying everyone the same price may be considered as fair (Ferraro 2008), but it is not guaranteed that it will result in a socially optimal allocation. A PES system benefiting the poor (as in Milder et al. 2010) is not based on the economic value of the ecosystem services and may not result in a socially optimal situation either. Because it is from an economic point of view to base the remuneration for the provided ecosystem service on the economic value of the service, our study contributes to governing the internalization of externalities in the PES systems.

To construct a socially optimum PES system, we develop an Economic Ecosystem governance framework (summarized as $\mathrm{Eco}^{2}$ governance framework) to provide a systematic guide through the relevant steps and information necessary for an entrepreneur to decide whether to invest in wetlands or not. This framework also shows the challenges for expansion of commercial wetlands. The framework allows us to analyze scaling issues for economic governance of wetlands if various services are provided simultaneously. Scale is defined as "the spatial, temporal, quantitative, or analytical dimensions used to measure and study any phenomenon" (Gibson et al. 2000:218).

The paper is organized as follows. First, the $\mathrm{Eco}^{2}$ governance framework that focuses on integrating wetland services in economic decision making is introduced, together with the relevant scales and levels. We apply the distinctive steps and scales in this framework to analyze challenges for expanding commercial wetlands, after which, conclusions are drawn.

\section{FRAMEWORK FOR INTEGRATING ECOSYSTEM SERVICES IN DECISION MAKING ON INVESTING IN COMMERCIAL WETLANDS}

To utilize commercial wetlands for solving social problems it is necessary to understand the provided ecosystem services, the value of these services, and the governance mechanism, i.e., economic governance structures, relevant for incorporating ecosystem services in private land use decisions. For this purpose we develop the $\mathrm{Eco}^{2}$ governance framework that enables the identification of challenges for the implementation of economic governance structures.

\section{Economic ecological governance framework}

The $\mathrm{Eco}^{2}$ governance framework is developed to analyze, and optimize from a social perspective, decision making about investing in commercial wetlands (Fig. 1). This figure is adapted from Reinhard et al. (2004) and Daily et al. (2009). Reinhard et al. (2004) constructed a framework based on DPSIR (Driving Forces-Pressures-StateImpacts-Responses), developed by the European Environmental Agency, to analyze the impact of various potential measures on the value of water. Further, they made use of programming cycles evaluation studies in which strategies, goals, inputs, activities, outputs, and expected effects are related (EC 1999). Daily et al. (2009) use a comparable framework to show how ecosystem services can be integrated into decision making. In this paper, we add the scaling perspective with a focus on the consequences for economic governance.

The $\mathrm{Eco}^{2}$ governance framework links the decision to invest in ecosystems (step 1) to the physical impact on the ecosystem (step 2). One of the distinguishing characteristics of commercial ecosystems is that it is the entrepreneur's voluntary decision to invest in ecosystems. In step 3, this impact is translated into an effect on the provision of ecosystem services in physical terms. In step 4, the value of the change in these services is computed. In the next step (5), governance mechanisms at different jurisdictional levels can internalize ecosystem service values. Governments can offer entrepreneurs remuneration schemes that are based on social values that give incentives to entrepreneurs to invest in commercial wetlands 
Fig. 1. Economic Ecosystem governance framework to analyze decision making about ecosystem services

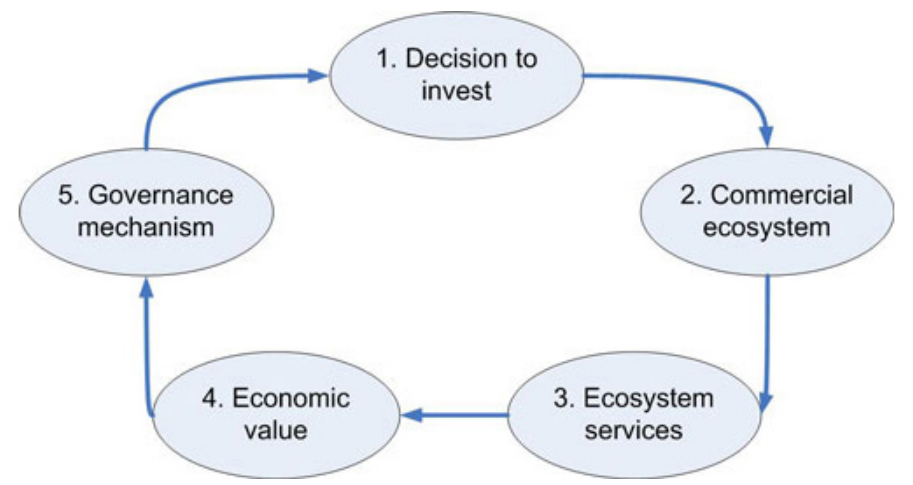

(step 1). We will limit our discussion to one cycle of the framework to avoid an overly complex presentation and apply the framework to a case study. However, our approach is an iterative process that allows for feedback loops based on the information in the previous loop.

Step 1, the decision to invest, to develop a commercial wetland, is based on the expected effect of this decision. If an entrepreneur considers investing in a commercial wetland, the sum of the expected revenues should be larger than the investment costs. Of course, we could also consider other objectives of the entrepreneur (see Jongeneel et al. 2008), but for the commercial exploitation, the ratio of revenues and costs is important.

In this paper, we use information from a pilot project in the neighborhood of Haaksbergen, in the eastern part of the Netherlands (Fig. 2). Within this project, a parcel of 3 ha of green maize has been transformed into a wetland called "Waterpark Het Lankheet." It is a pilot project to analyze the contribution of this type of wetland to the goals of the EU Water Framework Directive (WFD). This wetland was financed with a special governmental project subsidy. Here, we analyze the potential to expand this project country-wide on a commercial basis.

In step 2, if the entrepreneur invests in a commercial wetland, land such as agricultural land will be transformed into a multifunctional wetland. The socially optimal area of commercial wetlands will depend on the social demand for these wetlands.
The social demand is investigated in step 3, the provision of ecosystem services.

In Waterpark Het Lankheet, 3 ha of arable land was inundated and planted with reeds. The agricultural production was substituted for wetland's ecosystem services. The following services are taken into account:

- Water treatment in terms of nutrient concentration reduction with helophytefilters;

- Biomass production (to produce renewable energy);

- Capturing carbon;

- Solving desiccation problems in nature conservation areas;

- Water storage to avoid flooding;

- Recreation such as walking, cycling, picnicking, jogging, playing etc.

In step 3 , the ecosystem services provided by agriculture will be reduced and the services delivered by wetlands are increased. The magnitude of this change in functions can be computed with production functions. The ecosystem services provided depend on the location, e.g., the altitude and the proximity of water, and on the number of citizens that benefit from the commercial wetland. 
Fig. 2. Spatial ecosystem service scale and spatial beneficiaries scale per commercial wetland function.

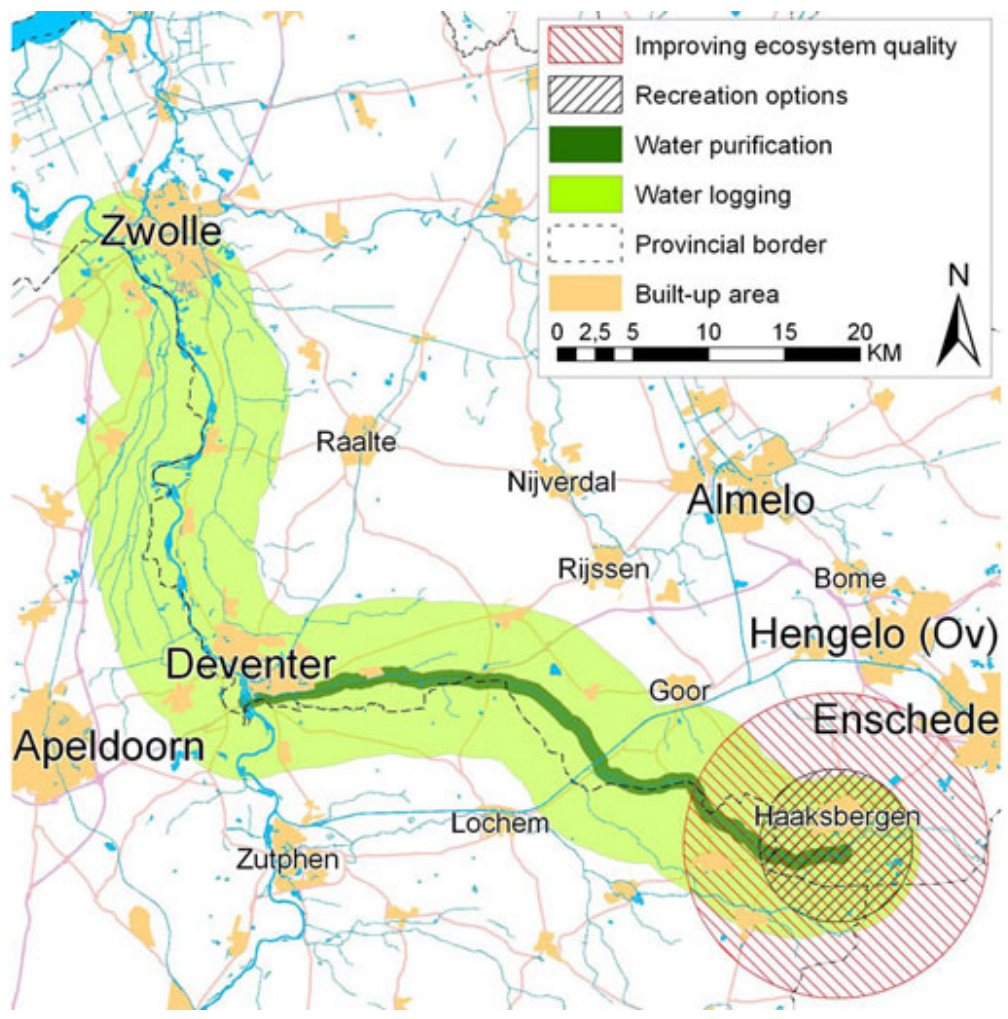

The ecosystem services have to be quantified to enable financial incentives related to these services (Engel et al. 2008).

The biophysical performance of Waterpark Het Lankheet is summarized in Table 1. From the research carried out at the Lankheet pilot project, it is known that depending on the residence time and volume per unit area, reed is capable of reducing the total amount of nitrogen in the water with average efficiencies from $32 \%$ to $47 \%$ and the total amount of phosphorous from $27 \%$ to $45 \%$ (Meerburg et al. 2010). This makes a biophysical performance of the water purification of $500 \mathrm{~kg} \mathrm{~N}$ and $50 \mathrm{~kg} \mathrm{P}$ per ha per year realistic. Biomass production varies from year to year, but an amount of 30 ton dry matter per ha is a reliable expectation (Duke 1983, Chiu and Wong 2006, Meerburg et al. 2010). The amount of $C$ captured by reed depends on the yield. Giving the chemical composition of reed, 1 ton of dry matter biomass consists of $400 \mathrm{~kg}$
C. This implies that 1 ha of reed producing 30 ton dry mater captures 12 ton $\mathrm{C}$. The service of peek water logging depends on the height of the dikes around the wetland. If $70 \mathrm{~cm}$ of extra water can be logged on the wetland, the service consists of 7000 $\mathrm{m}^{3}$ per ha.

Step 4 determines who benefits from the different ecosystems services at different spatial scales, and examines the value beneficiaries attached to different ecosystem services. The economic value element reflects the importance of the ecosystem services for the beneficiaries (Hein et al. 2006). We are aware of other important values, such as cultural and philosophical, or spiritual values, however in this paper we focus on monetary values because they are essential to enable a value-based incentive. The economic value depends on the preferences for ecosystem services of the beneficiaries who are affected by the decision to invest in commercial ecosystems. Beneficiaries can attribute four value 
Table 1. Scale value and governance issues attached to the implementation of commercial wetlands.

\begin{tabular}{|c|c|c|c|c|c|}
\hline \multicolumn{3}{|l|}{ Ecosystem Service } & \multicolumn{2}{|l|}{ Economic Value } & \multirow{2}{*}{$\begin{array}{l}\text { Economic Governance } \\
\text { Scale 5: } \\
\text { Jurisdictional scale }\end{array}$} \\
\hline $\begin{array}{l}\text { Wetland } \\
\text { service }\end{array}$ & $\begin{array}{l}\text { Scale 3: } \\
\text { Spatial ecosystem } \\
\text { service scale }\end{array}$ & $\begin{array}{l}\text { Biophysical } \\
\text { performance }\end{array}$ & $\begin{array}{c}\text { Scale 4: } \\
\text { Spatial } \\
\text { beneficiaries scale } \\
\text { (number of } \\
\text { households) }\end{array}$ & $\begin{array}{l}\text { Economic value } \\
\text { per beneficiary } \\
\text { (household) }\end{array}$ & \\
\hline Water purification & Downstream & $\begin{array}{l}500 \mathrm{~kg} \mathrm{~N} \text { per ha } \\
50 \mathrm{~kg} \mathrm{P} \text { per ha }\end{array}$ & 3640 & $€ 6.17$ & $\begin{array}{l}\text { Water board: Insufficient } \\
\text { water quality in a water } \\
\text { body }\end{array}$ \\
\hline Water logging & Downstream & $\begin{array}{l}7000 \mathrm{~m}^{3} \text { water } \\
\text { per ha }\end{array}$ & 128675 & $€ 6.38$ & $\begin{array}{l}\text { Water board: Flood and } \\
\text { high water risk }\end{array}$ \\
\hline $\begin{array}{l}\text { Improving } \\
\text { ecosystem quality }\end{array}$ & Wetland & $\begin{array}{l}\text { Improved } \\
\text { ecosystem } \\
\text { quality }\end{array}$ & 21165 & $€ 4.51$ & $\begin{array}{l}\text { Provinces: Desiccation } \\
\text { problems }\end{array}$ \\
\hline $\begin{array}{l}\text { Capturing CO2 } \\
\text { emissions }\end{array}$ & Global & 12 ton $\mathrm{C}$ per ha. & $\infty$ & $€ 3.71$ & \\
\hline $\begin{array}{l}\text { Biomass } \\
\text { production }\end{array}$ & At the spot & $\begin{array}{l}30 \text { ton dry } \\
\text { matter per ha }\end{array}$ & $1^{*}$ & $€ 0.00$ & Private actors \\
\hline $\begin{array}{l}\text { Recreation } \\
\text { options }\end{array}$ & At the spot & & 8655 & $€ 2.55$ & $\begin{array}{l}\text { Private actors } \\
\text { Municipality } \\
\text { Provinces }\end{array}$ \\
\hline
\end{tabular}

* The wetland entrepreneur

types to ecosystem services, namely: direct use values, indirect use values, option values, and nonuse values. Valuation methods have to be used to identify the value of the ecosystem services per beneficiary and the number of beneficiaries (Brown et al. 2007).

For Waterpark Het Lankheet, different wetland services are distinguished (see step 2 and 3). The economic value per beneficiary (household) depends on individual preferences for and use of the increased provision of wetland services. Because most of the provided wetland services are public good services, no market price exists. Biomass production is an exception. This could be seen as a private product that if traded, could have a market price. However, currently the market price for biomass-reed is negligible.
To calculate the total economic value of the public wetland services, a monetary valuation method is used to calculate the economic value per household expressed in willingness to pay (WTP). Households were asked their WTP to realize extra commercial wetlands in the Netherlands using the contingent valuation method (CVM). CVM is a survey-based valuation technique used for wetland valuation in economic literature (see, for instance, Barbier et al. 1997, Birol et al. 2006). The ecosystem services derived from commercial wetland are highly correlated, which makes it difficult to distinguish between individual services (Brouwer et al. 1999). To avoid double counting and because valuing the wetland services separately through individual CVM exercises could lead to seriously biased estimations, we applied the Analytical Hierarchical Process (AHP) to decompose the CVM value (see Kallas et al. 2007). 
The data was received from an internet questionnaire and collected in December 2008. The respondents were members of a panel of a specialized bureau (TNS-NIPO) and many socioeconomic characteristics were already known. The average time spent on filling out the valuation questionnaire could therefore be kept relatively short and respondents were remunerated for filling out complete questionnaires. Before the questionnaire was put online, it was pretested with a selected number of respondents. The sample of 826 respondents was representative of the Dutch population. The total economic value per household to realize exploitation of commercial wetlands to get better water quality, more water storage options to solve flooding, to solve desiccation problems, capture $\mathrm{CO} 2$ emissions via an increase in biomass production, and increase recreation options in the Netherlands is 23 euros per household. As shown in Table 1, the sum of the separated values add up to 23 euros. It appears that Dutch households have the highest WTP for the water purification and for the water logging services.

Step 5 presents the governance mechanisms in which the ecosystem services are embedded. The actual provision of ecosystem services depends largely on these institutions because they influence the decision making in step 1. A socially optimal institutional structure relates the societal demand for ecosystems services to the supply. It takes the social value of the ecosystem services into account to attain a socially optimal result. For most ecosystem processes, because of high transactions costs, the difficulty in attaching values to ecosystem services, and the nonexcludable character of the ecosystem services, no traditional market exists where price is the only coordination tool (Boyd and Banshee 2007, Brown et al. 2007, Kroeger and Casey 2007). To stimulate sustainable supply of commercial ecosystems next to markets of ecosystem products, other governance mechanisms, i.e., institutions, are necessary to provide the social demand of ecosystem services.

Waterpark Het Lankheet received subsidies because it acted as a pilot study to analyze the potential of this kind of measure to attain the water quality demanded by the WFD. These subsidies are not available for landowners who want to copy the waterpark concept on their own grounds. Wetlands are regarded as a more attractive measure than technical Wordlessness, because they are a voluntarily measure and they produce other ecosystem services simultaneously. They currently lack financial incentives for landowners. This means that commercial wetland entrepreneurs are not paid for the provision of the public ecosystem services and their contribution to different policy goals.

\section{Integrating scaling into the $\mathrm{Eco}^{2}$ governance framework}

In this section, we show that including the relevant scales into the $\mathrm{Eco}^{2}$ governance framework will provide additional information for the alignment of the economic governance, i.e., institutions, to stimulate and facilitate commercial wetlands. As Cash et al. (2006:8) argue, "most attention given to scale in studies of human-environment interactions has focused on spatial, temporal, and jurisdictional issues, there are other scales that may be worth considering in particular cases."

In their article, they also elaborate on the institutional, management, network, and knowledge scales. Different levels are distinguished on all these scales. We build on Cash et al. (2006) by defining the relevant scale for each step in the $\mathrm{Eco}^{2}$ governance framework (Fig. 3).

We first describe the appropriate levels of the different elements of the $\mathrm{Eco}^{2}$ governance framework, and illustrate each step with information on the actual commercial wetland Waterpark Het Lankheet.

Scale 1, the institutional scale, is regarded as a separate scale (Cash et al. 2006). Institutional arrangements, for example, not only have specific jurisdictional characteristics but also fall into a hierarchy of rules, ranging from basic operating rules and norms through to systems of rules for making constitutions (Ostrom et al. 1999). Under a low level on the institutional scale, stakeholders have to make specific institutional arrangements. Opening a decision making process involves transaction costs. The decision making system relevant for commercial wetlands first involves the private land owner(s). In cases of collective decision making where several owners are involved, the system becomes more complex.

The scale of step 2, 3, and 4 is predominantly the spatial scale. However, these scales are based on different sets of indicators. Therefore, we attach 
Fig. 3. Scales connected to the $\mathrm{Eco}^{2}$ governance framework

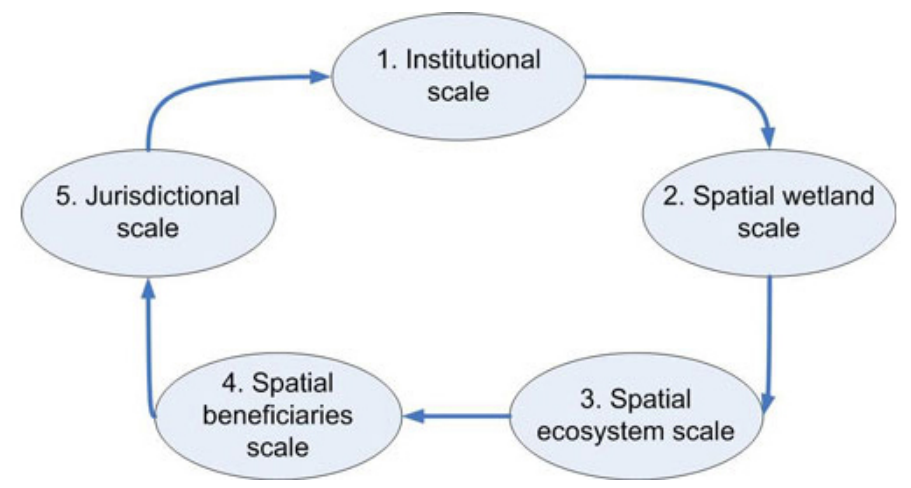

three different spatial scales to these steps. Scale 2 indicates the scale of the commercial wetland itself and is expressed in hectares. Scale 3 measures the impact of the commercial wetland, i.e., the effect of the ecosystem services. The unit of measurement depends on the specific service. Scale 4 includes the beneficiaries of the ecosystem services and is expressed in the number of households affected by the wetland's ecosystem services. We will describe these spatial scales in more detail. Step 5 is related to the jurisdictional scale (as in Cash et al. 2006).

Scale 2, the spatial wetland scale is defined as the size of the commercial wetland. The unit of analysis of this scale is hectare land use. The size is determined by the wetland ecosystem boundaries, selected by the land owner. The distribution of property rights and the attractiveness of wetland as a commercial land use affect the actual size of the wetland.

Scale 3, the spatial ecosystem service scale, is defined by the scale of the different ecosystem services provided by the wetland. The ecosystem services provided by a commercial wetland are based on different biophysical processes. The amount of water treatment depends for instance on the water quality entering the Waterpark (in $\mathrm{kg}$ phosphorus), the water flow (in $\mathrm{m}^{3}$ ) etc. The amount of carbon captured in the reed is a function of the reed yield. Models developed for these physical processes are useful to predict the delivery of ecosystem services (e.g., Tall is and Pol a sky 2009). The spatial ecosystem service scale quantifies and spatially maps the provision of ecosystem services.
The levels of the spatial ecosystem scale can be local (desiccation reduction and recreation), downstream (water storage and water treatment), and worldwide (capturing carbon). In Table 1, we schematically mapped the spatial ecosystem service scale of the 6 distinguished ecosystem services.

Scale 4, the spatial beneficiary scale, gives the number of households who benefit from the ecosystem services, and the spatial location of their residences. By investigating the demand for these services, the economic benefit per beneficiary per ecosystem service can be linked to specific beneficiaries. Beneficiaries at different spatialeconomic impact levels can attach different values to ecosystem services (Hein et al. 2006). The unit of analysis of the spatial-economic impact scale is the total value per service which depends on the number of beneficiaries and on the value per beneficiary of the changed ecosystem service provision (Hanley et al. 2003, Bateman et al. 2006, Villa et al. 2009).

The number of households that benefit from a specific ecosystem service depends on the location with respect to the wetland and the impact of the changed ecosystem service (see scale 3). To determine the impact of this scale, we analyzed the beneficiaries per spatial ecosystem scale (scale 3 ). For a realistic illustration, we used studies estimating distance decay functions for the value of ecosystem services, and expert knowledge (Bateman et al. 2006, Hime et al. 2009, Villa et al. 2009). The beneficiaries of water purification are assumed to be the farmers downstream, less than 
$500 \mathrm{~m}$ from the river. The beneficiaries of water storage are assumed to be the inhabitants of the area downstream, up to $5 \mathrm{~km}$ on both sides of the river. The living location of beneficiaries of the solution to desiccation problems is within the $10 \mathrm{~km}$ radius of the commercial wetland. The beneficiaries of improved recreation options live within $5 \mathrm{~km}$ of the commercial wetland. The benefits of $\mathrm{CO} 2$ reduction are global. Based on these assumptions, the beneficiaries of Waterpark Het Lankheet are given in Figure 2. In Table 1, the number of beneficiaries is quantified by the number of households living at a location where the specific commercial ecosystem service is provided by Waterpark Het Lankheet. We estimated this number with data from Statistics Netherlands.

Scale 5, the jurisdictional scale, is defined as clearly bounded and organized political units, with linkages between them created by constitutional and statutory means (Cash et al. 2006). Inclusion of this scale is necessary to investigate whether an organizational infrastructure is available to realize ecosystem service objectives. For provision of some ecosystem services, organizational infrastructure is developed by making clearly bounded and organized political units responsible for realizing objectives. These clearly bounded units, e.g., provinces, nations, etc., are the levels of the jurisdictional scale (Cash et al. 2006). None of these levels are responsible for the entire array of ecosystem services provided by Waterpark Het Lankheet as a whole.

For some of the ecosystem services provided by commercial wetlands, jurisdictional scales are available in the Netherlands. Provinces have jurisdiction over nature zoning policies whereas water boards are responsible for water related issues. For the ecosystem services 'reduced $\mathrm{CO} 2$ emissions' and 'improving recreation options', no single governmental organization has jurisdiction. The jurisdictional levels for the distinguished ecosystem services provided by Waterpark Het Lankheet are summarized in Table 1. The benefits of commercial wetlands are governed by different jurisdiction levels.

\section{ECONOMIC GOVERNANCE TO DELIVER COMMERCIAL ECOSYSTEM SERVICES}

In the previous section, the spatial ecosystem service, spatial beneficiary, and jurisdictional scales and levels relevant for governing the expansion of commercial wetlands are quantified and spatially mapped. To facilitate provision of ecosystem services through commercial wetlands, economic governance is necessary. Economic governance consists of the processes that support economic activity.

\section{Governance of commercial wetlands}

As discussed, commercial wetlands have multiple scales that go further than selling or buying biomass only. Wetlands are location specific because they are not only linked with the local physical environment but also with the skills of the entrepreneur and with the local population and its preferences for public goods. The public good characteristics of commercial wetlands require coordination of decision making. The economic governance in which supply and demand of different wetland services are coordinated can be seen as a form of hybrid governance structures. Hybrid governance structures (see Ménard 2004) maintain distinct and autonomous property rights of wetland owners and their associated decision rights. Coordination within hybrid governance goes far beyond what the price system can provide and thus makes them distinct from pure market arrangements (see for instance Ménard 2004). Taking into account the specificities of public goods elements of the ecosystem services provided by commercial wetlands, hybrid arrangements for these services can be regrouped according to the following categories (see also Van Huylenbroeck et al. 2009):

1. Information devices: a coordination center exists that provides information to coordinate the actions of the individual wetland entrepreneurs and individual beneficiaries of the ecosystem service provided. Achieving higher overall performance compared with uncoordinated actions of each wetland owner separately. This option does not affect jurisdictional scales.

2. Contractual arrangements: a coordination center exists that makes individual contracts with the entrepreneur who can render the different ecosystem services to society. This coordination center is a public body on behalf of beneficiaries. This body receives from the public authority the regulatory and incentive power and instruments, mostly on a 
contractual basis, to regulate, coordinate, and monitor wetland entrepreneurs. In this case, the jurisdictional scale has been changed.

3. Exogenous regulator or monitor: public authorities use an external, private or publicprivate, body as an intermediate body to coordinate the actions of individual entrepreneurs across different wetland services. Here the jurisdictional scale is not changed; however, structure is imposed to coordinate supply and demand of ecosystem services.

4. A governing body: in extreme cases the governing authority can decide to pass all legal power to a new public, private, or public-private body, that receives juridical and other power. Because of the great shift in property rights from private entrepreneurs to the governing body, this goes beyond the scope of this paper, which focuses on commercial wetlands.

This list is not complete, but it shows that depending on the situation at hand, different choices have to be made with respect to economic governance of commercial wetlands. The main economic challenges are addressed to answer the question: which governance mode is best suited for the provision of the socially optimal level of the commercial wetland services by commercial wetland entrepreneurs?

As illustrated in Table 1, the distinctive scales do not always match in practice. To include the value of the commercial wetland functions in investment decisions, the within- and cross-scales challenges to deliver the socially optimal level of ecosystem services are addressed. Within-scale is defined as interactions among levels inside a single scale, and cross-scale means interactions across different scales (see also Cash et al. 2006).

\section{Within-scale challenges}

\section{Marginal value challenge}

An advantage of commercial wetlands is that Adam Smith's invisible hand will lead to the optimal provision of commercial wetlands if the marginal value truly represents the value of the ecosystem services and inputs. To include the (positive) external effects of commercial wetlands, the compensation for the delivered wetland services has to be determined. This compensation has to be related to the marginal value. Table 1 presents the marginal economic values (scale 4 ) of six ecosystem services provided by Waterpark Het Lankheet (as described previously). Direct extrapolations of marginal values are difficult because extrapolation from the margin to a higher level should incorporate knowledge about the shape of the demand curve. For example, high local values of services such as water purification may not be maintained if extrapolated regionally or nationwide. The marginal value challenge is to determine the marginal value of commercial ecosystem services provided, if expanded to higher levels.

\section{Multi jurisdictional challenge}

Within scale 5 (see Table 1), constitutions at different jurisdictional levels attach property rights to the different ecosystem services. They specify land ownership, local governments, states, federal agencies, and international organizations (see Lueck 1989 for examples on wildlife laws). Within institutional economics it is assumed that higher institutional levels impose constraints on the level immediately below (see Williamson 2000). Lower levels give feedback to higher levels. Governance solutions with a lower level jurisdiction are nested within larger jurisdiction solutions (see Paavola 2007). Higher level jurisdictions like the European Union (e.g., Water Framework Directive) or the Dutch government are "constitutions" for jurisdictions at lower levels which still have their own decision making, monitoring, and implementation bodies and designated conflict resolution processes. This results in a multijurisdiction demand per ecosystem services. See in Table 1 for the wetland service 'water purification' example. The EU, the Dutch government, and the water boards have policy objectives for water quality. The water boards are responsible for the water quality in the Netherlands, creating demand for water purification. The challenge is to mutually fine-tune policy agendas and stakeholder interests operating across different institutional levels.

\section{Cross-scale challenges}

\section{Multifunctional land use challenges}

Because of different social and ecological changes, e.g., population growth, income growth, and climate 
change, a large number of societal claims on scarce urban land exists (Nijkamp et al. 2003). Commercial wetlands make efficient use of scarce land by combining different functions within one area intently, i.e., multifunctional land use. Governments at different levels frame problems so that these become tractable within their jurisdictions (see for instance Scott 1998, Lebel et al. 2005, as cited in Cash et al. 2006). Following Cash et al. (2006), potential mismatch problems result from the fact that the jurisdictional scale of the management institution is not coterminous with the problem, which is measured at the spatial ecosystem service scale.

A mismatch between the multiple and overlapping jurisdictions relevant for ecosystem services provided by commercial wetlands exists. Looking at the jurisdictional scale (scale 5), provincial authorities are responsible for realization at the spatial ecosystem service scale (scale 3) of recreation and improving ecosystem quality; the nature and landscape aspects of wetlands. They do not have comparable jurisdiction over both water quality and water quantity related issues. The provinces and linked zoning policies related to nature and landscape are mainly nested within the Ministry of Agriculture, Nature and Food Quality and the Ministry of Economic Affairs. Water related policies are mainly the responsibility of the Ministry of Transport, Public Works and Water Management. In the Netherlands, all kinds of institutional arrangements are present to align different policy objectives originating from jurisdictions. The responsible jurisdictional levels for commercial wetlands can be considered as taskspecific jurisdictions instead of general purpose jurisdictions (see Hooghe and Marks 2003). This implies that some element of coordination will be required across policy regimes (Hodge 2007). The multifunctional land use challenge is to obtain the required level of coordination between the responsible jurisdictional levels.

\section{Economic benefit challenge}

Governance needed for the implementation of PES payment schemes for the provision of commercial wetland services should, from an economic point of view, be based on the monetary value of these services (scale 4). These values are spatially distributed and do not entirely fit within the jurisdiction boundaries, so the spatial beneficiary scale and the jurisdictional scale do not match.
In economic theory, the responsible jurisdictional level is known as the political jurisdiction (scale 5), while the beneficiaries live within the economic jurisdiction (scale 4). The spatial beneficiary scale (the economic jurisdiction) does not coincide with those that are able to give incentives to entrepreneurs to develop commercial wetlands (political jurisdiction). Bateman et al. (2006) showed that the political and the economic jurisdictions in most cases do not match. To include the sum value of the ecosystem services in the PES system, a related challenge is that the value is not equally distributed over the beneficiaries. The values are expected to reduce with increasing distance from the commercial ecosystem. The challenge is to decide which political jurisdiction is able to transfer the value of the beneficiaries best.

The more ecosystem services are provided simultaneously, the more difficult to get a payment for ecosystem services based on the social value of the exchanging ecosystem services. One reason for this is the separated responsibility of the ecosystem services over different jurisdictional levels (scale 5), making the transaction costs relatively high compared with the value per service (scale 4). The challenge is to construct a PES system for a wetland providing many different ecosystem services, taking into account the social value of the different services.

\section{Negotiation challenge}

A single beneficiary approach that ignores the multitude of connections among the wetland services of commercial ecosystems will fail to provide a high value for society. The complete bundle of services the wetland can produce will generate more welfare for society (see Tallis and Polaski 2009 for sector approaches). To translate the value of the ecosystem services in adequate PES schemes, negotiation is needed (see also de Groot and Hermans 2009). To do this, different types of negotiations can be distinguished, namely, political negotiations within the jurisdictional level responsible for one commercial ecosystem service, negotiation between the different responsible jurisdictional levels, and negotiation between the demand side and the commercial wetland entrepreneur. This implies a complex negotiations process. The challenge is to structure this process, and to include all the responsible jurisdictional levels (scale 5) in the complex negotiation process. 


\section{CONCLUSIONS}

To facilitate the socially optimal provision of ecosystem services provided by commercial wetlands, we developed a framework to link ecosystem services with public and private decision making. This $\mathrm{Eco}^{2}$ governance framework combines the private investment in commercial wetland decisions with the social value of the produced services. Possible economic governance systems can be proposed to give incentives for private investments in these wetlands. However, a number of challenges have to be addressed before investments in commercial wetlands can be profitable. These challenges are analyzed using the observation that the five elements in the $\mathrm{Eco}^{2}$ governance framework are measured in different scales, and that within these scales different levels are found.

From the application of the framework in a pilot study in the eastern part of the Netherlands, it followed that the expansion of the concept to a national level will currently be almost impossible. This is due to the mismatch between the scales related to the provided ecosystem services, the demand of the wetland services, and the jurisdictional scale. If commercial wetlands are optimal from social planners' point of view, they can hardly be implemented privately. This goes beyond the fact that many of the services are public goods. To match these ecosystem services and to enable the implementation of commercial wetlands, institutional solutions need to fit different services.

Given that property rights to private wetlands remain distinct and autonomous, the governance choice can be (1) just exchanging information, (2) a new jurisdictional level responsible for all types of wetland services, or (3) an intermediary private organization that coordinates on behalf of entrepreneurs. The first option will be weak in coordinating supply and demand. Changing jurisdictional responsibilities only for implementation of commercial wetlands will involve relatively high transaction costs. Despite which governance approach will be implemented, developing economic governance solutions will help to arrange an optimal allocation of commercial wetlands. The framework developed in this paper can support this process in a structured way by combining commercial wetlands, ecosystem services, and governance.
Responses to this article can be read online at: http://www.ecologyandsociety.org/voll6/iss 1/art33/ responses/

\section{Acknowledgments:}

We thank the editor and two anonymous reviewers for their valuable comments on an earlier draft version. This research is part of the strategic research program "Sustainable spatial development of ecosystems, landscapes, seas and regions" and is funded by the Dutch Ministry of Agriculture, Nature Conservation, and Food Quality and by BSIK Leven met Water. This paper is also written in the context of the IP/OP 'Scaling and Governance' Research Program, which has been spearheaded by Wageningen University and Research Centre Wageningen UR, as part of its mission to contribute to solutions for the most pressing global environmental problems.

\section{LITERATURE CITED}

Barbier, E. B., M. Acreman, and D. Knowler. 1997. Economic valuation of wetlands: a guide for policy makers and planners. Ramsar Convention Bureau, Gland, Switzerland.

Bateman, I. J., B. H. Day, S. Georgiou, and I. Lake. 2006. The aggregation of environmental benefit values: welfare measures, distance decay and total WTP. Ecological Economics 60(2):450-460.

Birol, E., K. Karoukasis, and P. Koundouri. 2006. Using economic valuation techniques to inform water resources management: a survey and critical appraisal of available techniques and application. Science of the Total Environment 365:105-122.

Boyd, J., and S. Banzhaf. 2007. What are ecosystem services? The need for standardized environmental accounting units. Ecological Economics 63 (2-3):616-626.

Brouwer, R., I. H. Langford, I. J. Bateman, T. C. Crowards, and R. K. Turner. 1999. A meta analysis of wetland contingent valuation studies. Regional Environmental Change 1:47-57. 
Brown, T. C., J. C. Bergstrom, and J. B. Loomis. 2007. Defining, valuing and providing ecosystem services. Natural Resources Journal 47(2):329-376.

Bulc, T. G., and A. J. Slak. 2009. Ecoremediations a new concept in multifunctional ecosystem technologies for environmental protection. Desalination 246:2-10.

Cash, D. W., W. Adger, F. Berkes, P. Garden, L. Lebel, P. Olsson, L. Pritchard, and O. Young. 2006. Scale and cross-scale dynamics: governance and information in a multilevel world. Ecology and society 11(2): 8. [online] URL: http://www.ecology andsociety.org/vol11/iss2/art8/.

Chiu, K. K., Z. H. Ye, and M. H. Wong. 2006. Growth of Vetiveria zizanioides and Phragmites australis on $\mathrm{Pb} / \mathrm{Zn}$ and $\mathrm{Cu}$ mine tailings amended with manure compost and sewage sludge : a greenhouse study. Bioresource technology 97 (1):1-14.

Daily, G. C., S. Polasky, J. Goldstein, P. M. Kareiva, H. A. Mooney, L. Pejchar, T. H. Ricketts, J. Salzman, and R. Shallenberger. 2009. Ecosystem services in decision making: time to deliver. Frontiers in Ecology and the Environment 7 (1):21-28.

de Groot, R. B. A., and L. M. Hermans. 2009. Broadening the picture: negotiating payment schemes for water-related environmental services in the Netherlands. Ecological Economics 68:2760-2767.

de Jonge, V. N. 2009. From a defensive to an integrated approach. Pages 17-46 in S. Reinhard and $\mathrm{H}$. Folmer, editors. Water policy in the Netherlands: integrated management in a densely populated delta. Resources for the Future, Washington, D.C., USA.

Duke, J. A. 1983 Handbook of energy crops. Center for New Crops and Plant Products, Purdue University, West Lafayette, Indiana, USA. [online] URL: http://www.hort.purdue.edu/newcrop/duke energy/ dukeindex.html.

European Commission (EC). 1999. Evaluation design and management; evaluating socioeconomic programmes. MEANS collection Volume 1. European Commission, Luxemburg.
Engel, S., S. Pagiola, and S. Wunder. 2008. Designing payments for environmental services in theory and practice: an overview of the issues. Ecological Economics 65:663-647.

Ferraro, P. J. 2008. Asymmetric information and contract design for payments for environmental services. Ecological Economics 65(4):810-821.

Gibson, C., E. Ostrom, and T.-K. Ahn. 2000. The concept of scale and the human dimensions of global change: a survey. Ecological Economics 32:217-239.

Hanley, N., F. Schläpfer, and J. Spurgeon. 2003. Aggregating the benefits of environmental improvements: distance-decay functions for use and non-use values. Journal of Environmental Management 68(3):297-304.

Hein, L. G., C. S. A. van Koppen, R. S. de Groot, and E. C. van Ierland. 2006. Spatial scales, stakeholders and the valuation of ecosystem services. Ecological Economics 57(2):209-228.

Hime, S., I. J. Bateman, P. Posen, and M. Hutchins. 2009. A transferable water quality ladder for conveying use and ecological information within public surveys. CSERGE Working Paper EDM 09-01. The Centre for Social and Economic Research on the Global Environment, Norwich, UK.

Hodge, I. 2007. The governance of rural land in a liberalized world. Journal of Agricultural Economics 58(3):409-432.

Hooghe, L., and G. Marks. 2003. Unrevealing the central state, but how? Types of multi-level governance. The American Political Science Review 97(2):233-243.

Jongeneel, R. A., N. B. P. Polman, and L. H. G. Slangen. 2008. Why are Dutch farmers going multifunctional? Land use policy 25:81-94.

Kallas, Z., J. A. Gomez-Limon, and J. Barreir Hurle. 2007. Decomposing the value of agricultural multifunctionality: combining contingent valuation and the analytical hierarchy process. Journal of Agricultural Economics 58(2):218-241. 
Kroeger, T., and F. Casey. 2007. An assessment of market-based approaches to providing ecosystem services on agricultural lands. Ecological Economics 64(2):321-332.

Lueck, D. 1989. The economic nature of wildlife law. Journal of Legal Studies 18(2):291-324.

Meerburg, B. G., P. H. Vereijken, W. de Visser, A. Verhagen, H. Korevaar, E. P. Querner, A. T. de Blaeij, and A. van der Werf. 2010. Surface water sanitation and biomass production in a constructed wetland: pilot Lankheet. Wetlands, Ecology and Management 18(4):463-470.

Ménard, C. 2004. The economics of hybrid organizations. Journal of Institutional and Theoretical Economics 160:345-376.

Milder, J. C., S. J. Scherr, and C. Bracer. 2010. Trends and future potential of payment for ecosystem services to alleviate rural poverty in developing countries. Ecology and Society 15(2): 4. [online] URL: http://www.ecologyandsociety.org/vol15/ iss2/art4/.

Millennium Ecosystem Assessment. 2005. Ecosystem and human well-being: a frameworkfor assessment. Island Press, Washington, D.C., USA. [online] URL: http://www.maweb.org/en/Framework.aspx

Ministry of Transport, Public Works and Water Management. 2007. Safeguarding our future; the government's vision of national water policy. The Hague, The Netherlands.

Mitsch, W. J., and J .G. Gosselink. 2000. The value of wetlands: importance of scale and landscape setting. Ecological Economics 35(1):25-33.

Nijkamp, P., C. Rodenburg, and R. Vreeker. 2003. The economics of multifunctional land use; experiences and policy lessons. Shaker Publishing, Maastricht, The Netherlands.

Ostrom, E., J. Burger, C. B. Field, R. B. Norgaard, and D. Policansky. 1999. Revisiting the commons: local lessons, global challenges. Science 284:278-282.

Paavola, J. 2007. Institutions and environmental governance: a reconceptualization. Ecological Economics 63:93-103.
Reinhard, S., A. Gaaff, J. van Bakel, and K. van Bommel. 2004. Waarderen van water in een regionaal watersysteem. [Valuation of water in a regional water system]. LEI-rapport. 4.04.03. The Hague, the Netherlands.

Scott, J. C. 1998. Seeing like a state: how certain schemes to improve the human condition have failed. Yale University Press, New Haven, Connecticut, USA.

Tallis, H., and S. Polasky. 2009. Mapping and valuing ecosystem services as an approach for conservation and natural-resource management. The Year in Ecology and Conservation Biology 1162:265-283.

Van Huylenbroeck, G., A. Vuylsteke, and W. Verbeke. 2009. Public good markets: the possible role of hybrid governance structures in institutions for sustainability. Pages 175-191 in V. Beckmann and M. Padmanabhan, editors. Institutions and sustainability. Springer Science+Business Media, New York, New York, USA.

Vatn, A. 2010. An institutional analysis of payments for environmental services. Ecological Economics 69(6):1245-1252.

Veldkamp, A., N. Polman, S. Reinhard, and M. Slingerland. 2011. From scaling to governance of the land system: bridging ecological and economic perspectives. Ecology and Society 16(1): 1. [online] URL: http://www.ecologyandsociety.org/vol16/iss1/ art1/.

Villa, F., M. Ceroni, K. Bagstad, G. Johnson, and S. Krivov. 2009. ARIES (Artificial Intelligence for Ecosystem Services): a new tool for ecosystem assessment, planning, and valuation. Paper presented at the 11th Annual BIOECON Conference on Economic Instruments to Enhance the Conservation and Sustainable Use of Biodiversity, 21-22 September, Venice, Italy. [online] URL: htt p://www.ucl.ac.uk/bioecon/11th 2009/Villa.pdf.

Williamson, O. E. 2000. The new institutional economics: taking stock, looking ahead. Journal of Economic Literature XXXVIII:595-613.

Wünscher, T., S. Engel, and S. Wunder. 2008. Spatial targeting of payments for environmental services: a tool for boosting conservation benefits. Ecological Economics 65(4):822-833. 